Atomic Energy for Military Purposes

The Official Report on the Development of the Atomic Bomb under the auspices of the United States Government, 1940-1945. By Henry DeWolf Smyth. Pp. viii $+308+8$ plates 0 Princeton, N.J. : Princeton University Presin UXon: Oxford University Press, 1946.) 12s gâ net.

TN Nature offDecfnber 29, 1945, p. 768, an article 1 by Prgf. If Feather surveyed and discussed the official Afenican report on the development of the atomid bo mb which was issued under the title "Atomc Energy for Military Purposes" and was quickly to be known as the Smyth Report, after its author. The report was re-issued in Great Britain by H.M. Stationery Office. Now the Princeton University Press has published the pamphlet in book form "as a public service in accordance with its purpose as a non-profit organisation seeking to disseminate the results of scholarly and scientific research". No royalty or other compensation is being paid to the author.

Substantially the report is a re-issue of the original pamphlet. Minor changes have been made, and a paragraph on radioactive effects, issued by the U.S. War Department, has been included ; an appendix consisting of the official account of the New Mexico test of July 15, 1945, has been added, and two further appendixes comprise the British Information Service statement, "Britain and the Atomic Bomb", dated August 12, 1945, and the Canadian Information Service statement dated August 13, 1945. There are also some photographs of the production plants and of the results of the explosion of the test bomb in New Mexico; and name and subject indexes are valuable additions.

This volume thus brings together the three official statements on the work on nuclear energy done during the War in a compact and convenient form which will be widely welcomed.

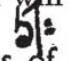

Papers of the Michigan Academy of Science, Arts and Letters

Vol. 28 (1942). Pp. xiils 701. (Ann Arbor, Mich. : University of M University Press, 123.) 28s. net.

7 HIS volupe consists of a series of papers under the difisipns of botany, forestry, zoology, geofrap ley, geology, anthropology, folk-lore, history, language and literature, medical science and philosophy.

Five of the botanical papers deal with algæ from Haiti, Hong Kong, South-east United States, and the Philippines.

A paper on "Some Resupinate Polypores from the Region of the Great Lakes" by D. V. Baxter, University of Michigan, is the fourteenth part of a monograph on this subject; other numbers having dealt with material from Alaska, the Yukon Territory and the North West Territories. A large number of resupinate polypores of northern Europe and Asia are indigenous to the region of the Great Lakes. Furthermore the majority of porias which occur in Michigan, Minnesota and Wisconsin can be found throughout the United States. There are, however, certain variants and forms in different localities; some are correlated with the occurrence of different types of substrata, others macroscopic variations due to moisture conditions. Races or strains occur, and can be separated from each other largely on a basis of their growth reactions in media.
Among the zoological papers is an account of "Mass Hybridization between two Genera of Cyprinid Fishes in the Mohave Desert, California", by C. L. Hubbs and R. R. Miller, University of Michigan. The study is one of several by which the authors are attempting to determine how the distribution and speciation of the fishes of the American desert have been affected by the profound hydrographic changes that occurred during and after Quaternary times \section{An Experimental Introfuction to the Theory of Probability}

By J. E. Kerrkd Pp. 98. (Copenhagen : Einar Munksgaard, 19 6.) 8.50 kroner.

W ${ }^{H E}$ Denmark was overrun by the Germans varioy British subjects were caught, $\mathrm{Mr}$. Ke fdr among them. He was interned in a camp under Danish control and spent part of his enforced leisure in coin-tossing experiments. This brochure, also completed in the internment camp, is written around the experimental results in an endeavour to provide a practical approach to the statistical theory of probability.

By an analysis of the observations, Mr. Kerrich introduces the idea of relative frequency as the basis of measurement of probability and shows how the elementary laws of addition and multiplication emerge as experimental facts for sequences of 'independent' events. He recognizes the logical difficulties but does not allow them to impede his progress, his main object being to provide an introduction to the study of probability for the average scientific student. The treatment is taken as far as the binomial distribution and the normal approximation to it.

Whatever views are held about the basis of the concept of probability there seems little doubt that students who meet it for the first time are helped to strengthen their faith by experimental work with coins or random numbers. Mr. Kerrich's brochure will be useful to such students, and his general approach could be studied with profit by teachers.

\section{British Association for the Advancement of Sciehce Mathematical Tables}

Vol. 1 : Circular and Hyperbole Functions, Exponential and Sine and Cosine In Arals, Factorial Function and Allied Functions, $y^{2}$ r pitian Probability Functions. Prepared oy thed chl hittee for the Caleulation of Mathematical fables. Second edition. Pp. xi +72 . (London: Cambridge University Press, 1946.) $10 s$. net.

THE Antition of these useful tables was pulfinted in 1931, and reviewed in Nature of May 4, 433. In the second edition the table of the fedtoxial or gamma function has been extended from thld recent computation to 18 places of decimals by Mr. S. Johnston. A few errors in the other tables have been corrected. Those who possess the first edition may obtain a list of these corrections on application to the Office of the British Association, Burlington House, London, W.1. The elaborate introduction that appeared in the first edition has been greatly reduced; the portions that have been deleted are those concerning the history of the Committee, the formulæ used in the computation of the tables, bibliographical references, and an account of the Hermitian Hh functions. What is left is the portion directly useful to the user of the tables. Computers are deeply indebted to Prof. E. H. Neville and his colleagues for their arduous labours. 